\title{
Ethno-Veterinary Practices Adaptation for Management of Poultry Diseases in Erode District
}

\author{
S. Vinothraj ${ }^{1 *}$, P. Alagesan ${ }^{2}$ and M. Siva ${ }^{2}$ \\ ${ }^{1}$ Animal Science, ${ }^{2}$ Home Science, ICAR-Krishi Vigyan Kendra (Myrada), \\ Erode District, TamilNadu-638453, India \\ *Corresponding author
}

\section{A B S T R A C T}

\section{Keywords \\ New Castle disease, Ethno-Veterinary Herbs and Backyard chicken \\ Article Info \\ Accepted: \\ 20 March 2019 \\ Available Online: \\ 10 April 2019}

\begin{abstract}
A study was conducted to assess the ethno veterinary practices adopted by rural chicken farmers for management of important diseases in native chickens was conducted in eight villages involving 320 backyard poultry farmers in T.N. Palayam, Gobi and Anthiyur block of Erode district, Tamil Nadu. The results indicated that majority of the rural chicken farmers used ethno-veterinary Herbs like Pepper, Black mustard, Kilanelli, Seeragam, Venkayam,Manjal, Vasambu, Kasakasa and Vembu for the management of chickens suffering from ND, Fowl pox, Ectoparasite infestation, Fever, Enteritis and wound. It was concluded that ethno- veterinary practices have been found to be widely used by rural chicken farmers in Erode district of Tamil Nadu.
\end{abstract}

\section{Introduction}

In India backyard poultry rearing is old as its civilization, required small space, low capital investment, quick return and well distributed turnover throughout the year make poultry farming remunerative. Due to commercialization of native chicken farming in India, the incidence of infectious diseases like Newcastle disease and fowl pox is increasing. In order to control various poultry diseases, ethno-veterinary medicine is widely practiced by poor village farmers. The use of ethno veterinary medicine can be considered sustainable as it is economical, culturally acceptable and ecologically sound. EthnoVeterinary is a branch of science deals with the study of traditional knowledge, methods, skills and practices are used for treating various ailments of animals (McCorkle, 1986). However, economic dependence on livestock, lack of effective veterinary infrastructure, etc. have forced the local farmers even today to apply their indigenous knowledge to look after and maintain their livestock population. Hence, the present work is perhaps the detailed record on EthnoVeterinary practices which was followed by Village farmers to manage Poultry diseases in Erode district of Tamil Nadu. 


\section{Study area}

The present study is carried in eight villages involving 320 backyard poultry farmers in T.N.Palayam, Gobi and Anthiyur block of Erode district, Tamil Nadu. Erode District lies on the extreme north of Tamil Nadu. It is bounded mostly by Karnataka State and also River Palar covers pretty long distance. To the East lies Namakkal and Karur Districts. Dindigal District is its immediate neighbour to the South and on the West; it has Coimbatore and Nilgiri Districts, as its boundaries. Thus Erode District is essentially a land-locked area having no sea-cost of its own. Erode District situated at between 10 36" and 11 58" North Latitude and between 76 49" and 77 58" East Longitude. The region comprised in the district can be portrayed as a long undulating plain gently sloping towards the river Cauvery in the south-east. The two major tributaries of river Cauvery viz. Bhavani and Noyyal drain the long stretch of mountains in the north. A part of the eastern boundary of the district is formed by river Cauvery, entering the district from Salem and flowing in a southern direction.

\section{Materials and Methods}

The survey was conducted during the year of 2018-2019. Ethno-veterinary information was gathered from all categories of village level backyard poultry farmers by direct contact. Medicinal plants survey were conducted mainly in Singiripalayam, Kochikallur, Bungalowputhur, Athani, Bhavani sagar, Kolappalur and Kavindapadi villages of Erode District. The present study data were collected from 50 Backyard poultry farmers with the average age of 35-70 of the study area who have much knowledge on medicinal plants with unstructured interview. The interviews were conducted in the local language, i.e., Tamil. Ethno-veterinary information included with the local name, parts used, preparation methods and mode of administration and allopathic treatment procedures for treating the Poultry diseases also collected. Preferential ranking technique (RBQ) was utilized to identify the Adaptation practices followed by farmers for treating the poultry diseases.

\section{Results and Discussion}

The results indicated that majority of the rural chicken farmers used ethno-veterinary medicines for the management of chickens suffering from major diseases like ND, Fowl pox and ectoparasite infestation. The present study Ethno-Veterinary Herbal Medicines practices were comparable with most of the earlier reports: Allium cepa is having many therapeutic properties like anti-inflammatory, antiseptic, antispasmodic and diuretic activity (Kumar et al., 2010). Patel et al., (2011) reported that $P$. amarus showed a wide spectrum of pharmacological activities including antiviral, antibacterial and antiinflammatory properties. Cumin and its active constituents used as antibacterial, antifungal, anti-inflammatory, antioxidant and immune modulation (Kaur and Sharma, 2012; Singh et al., 2017). Arthanari Eswaran et al., 2018 study reported that Phyllanthus amarus $100 \mathrm{~g}$ of whole plant, Cuminum cyminum-25g of seeds and Allium cepa pulp-10 numbers were taken and ground along with jaggery in to a pasty consistency used to treat New castle disease in 25 birds (Table 1).

In conclusion, these results showed that the ethno-veterinary practices play an important role in treatment of Poultry diseases in Erode district. Further it is emphasized that backyard chicken should also be vaccinated against major diseases regularly for prevention of the disease. 
Table.1 Documented Ethno-veterinary practices followed by the farmers for treatment of Poultry diseases in Erode district

\begin{tabular}{|c|c|c|c|c|c|}
\hline S. No & $\begin{array}{l}\text { Local } \\
\text { Name }\end{array}$ & Scientific Name & Disease & $\begin{array}{l}\text { Method of preparation } \\
\text { \& Administration }\end{array}$ & $\begin{array}{l}\text { Adaptation } \\
\text { percentage }\end{array}$ \\
\hline 1. & Pepper & Piper nigrum $L$. & \multirow[t]{4}{*}{$\begin{array}{l}\text { Ranikhat } \\
\text { Disease }\end{array}$} & $\begin{array}{l}\text { Grind } 20 \mathrm{~g} \text { seeds and } \\
\text { mixed with } 500 \mathrm{ml} \text { warm } \\
\text { water and drench once to } \\
\text { ranikhet disease. }\end{array}$ & 34.5 \\
\hline 2. & $\begin{array}{l}\text { Black } \\
\text { mustard }\end{array}$ & $\begin{array}{l}\text { Brassica nigra } \\
\text { L.Seeds }\end{array}$ & & $\begin{array}{l}\text { Grind } 50 \mathrm{~g} \text { seeds and } \\
\text { mixed with liltre of warm } \\
\text { water and drench once to } \\
\text { ranikhet disease. }\end{array}$ & 18.5 \\
\hline 3. & $\begin{array}{l}\text { Kilanelli } \\
\text { Seeragam }\end{array}$ & $\begin{array}{l}\text { Phyllanthus } \\
\text { amarus } \\
\text { Cuminum } \\
\text { cyminum }\end{array}$ & & $\begin{array}{l}\text { Phyllanthus amarus } 100 \mathrm{~g} \\
\text { mixed with } 20 \text { gram seeds } \\
\text { of Cuminum cyminum and } \\
\text { given orally for three } \\
\text { days. }\end{array}$ & 47 \\
\hline 4. & Venkayam & Allium cepa $L$. & & $\begin{array}{l}\text { Cut pieces of small onion } \\
\text { given for three days }\end{array}$ & 40.5 \\
\hline \multirow[t]{2}{*}{4.} & Manjal & $\begin{array}{l}\text { Curcuma longa } \\
\text { L. }\end{array}$ & \multirow[t]{2}{*}{ Fowl Pox } & $\begin{array}{l}\text { Turmeric powder mixed } \\
\text { with Neem paste for } \\
\text { external application }\end{array}$ & 75.6 \\
\hline & & & & $\begin{array}{l}\text { Neem bark @ } 1 \mathrm{~kg} / 1000 \\
\text { birds to be given after } \\
\text { soaking in water, over } \\
\text { night and Neem leaves as } \\
\text { top dressing. }\end{array}$ & 24.4 \\
\hline 5. & Vasambu & $\begin{array}{l}\text { Acorus calamus } \\
L\end{array}$ & \multirow[t]{2}{*}{$\begin{array}{l}\text { Ectoparasite } \\
\text { Infestation }\end{array}$} & $\begin{array}{l}\text { Acorus calamus is ground } \\
\text { and then applied over the } \\
\text { affected area of the skin } \\
\text { in hen }\end{array}$ & 45 \\
\hline 6. & $\begin{array}{l}\text { Nochi- } \\
\text { Leaves }\end{array}$ & Vitex negundo L. & & $\begin{array}{l}\text { Smoke of notchi leaf is to } \\
\text { control the ectoparasities }\end{array}$ & 55 \\
\hline 7. & Venkayam & Allium cepa $L$. & Fever & $\begin{array}{l}\text { Fresh onion stem are } \\
\text { given internally for } \\
\text { parasites or fever to hen. }\end{array}$ & - \\
\hline 8. & Kasakasa & $\begin{array}{l}\text { Papaver } \\
\text { somniferum L. }\end{array}$ & Enteritis & $\begin{array}{l}\text { Paste of seeds }(100 \mathrm{~g}) \text { is } \\
\text { administrated to treat the } \\
\text { enteritis and } \\
\text { gastroenteritis. }\end{array}$ & - \\
\hline 9. & Vembu & $\begin{array}{l}\text { Azadirachta } \\
\text { indica A. Juss. }\end{array}$ & Wound & $\begin{array}{l}\text { Neem oil is used for } \\
\text { wound healing }\end{array}$ & - \\
\hline
\end{tabular}


Ethno veterinary medicine is a natural and economical method to treat many diseases under field conditions (Sribalaji and Vikramachakravarthi, 2010; Sakthi Priya and Gopala Krishna Murthy, 2017).

\section{References}

Arthanari Eswaran M, Mekala P, Vadivoo VS and Sukumar K. Incidence of Newcastle disease in desi chicken and its control through ethno veterinary medicines. Journal of Pharmacognosy and Phytochemistry, 2018; 7(6): 14181419.

Kumar KPS, Bhowmik D, Chiranjib, Biswajit, Tiwari P. Allium cepa: A traditional medicinal herb and its health benefits. Journal of Chemical and Pharmaceutical Research, 2010; 2(1):283-291.

McCorkle CM. An Introduction to ethnoVeterinary research and development. Journal of Ethnobiology, 1986; 6: 129-149.

Patel JR, Tripathi P, Sharma V, Chauhan NS, Dixit VK. Phyllanthus amarus: Ethnomedicinal uses, phytochemistry and pharmacology: A review. Journal of Ethnopharmacology, 2011; 138:286-313.

Sakthi Priya M, Gopala Krishna Murthy TR. Constraints Encountered by Farmers in Adopting Ethno Veterinary Practices in Desi Bird Rearing in and Around Rural Areas of Namakkal District. Indian Veterinary Journal, 2017; 94(10):42-45.

\section{How to cite this article:}

Vinothraj, S., P. Alagesan and Siva, M. 2019. Ethno-Veterinary Practices Adaptation for Management of Poultry Diseases in Erode District. Int.J.Curr.Microbiol.App.Sci. 8(04): 27582761. doi: https://doi.org/10.20546/ijcmas.2019.804.321 